\title{
Translation of Proper Names in The Slippery Slope: Rendering Form, Meaning and Effect
}

\author{
Melinda Vernanda ${ }^{1}$, Bayu Budiharjo ${ }^{2}$ \\ \{melinda@student.uns.ac.id ${ }^{1}$, budiharjo_b@staff.uns.ac.id ${ }^{2}$ \}
}

Universitas Sebelas Maret, Surakarta, Indonesia ${ }^{1,2}$

\begin{abstract}
Translating proper names is not a non-trivial issue as translator needs to take the specific features of such linguistic units into consideration. Names of persons or things can be translated into their natural counterparts in the target language, in the manners commonly discovered in numerous translation works. Translating these names, however, turns into more problematic task when they bring with them particular meaning and stylistic effect, which requires proper rendering into the target language. This paper aims to study how proper names in the novel "The Slippery Slope" are translated from English into Indonesian. The analysis is focused on answering the inquiry concerning form, meaning, and stylistic effect in the source language and in the target language. The data take form of proper names of different categories. Data analysis was conducted by applying Miles and Huberman's interactive data analysis consisting of data reduction, data display and conclusion drawing. An initial analysis of 114 names and their translation were analyzed and the analysis reveal that most translations of proper names in the novel successfully deliver the form and the style in the target language in addition to the content within the proper names. This suggests that the translator attempts not only to convey the message but also the forms and stylistic effect within the original names.
\end{abstract}

Keywords: proper names translation, The Slippery Slope, form, meaning, stylistic effect.

\section{Introduction}

English novels, as fictional works, have been translated worldwide into various languages, including Indonesian. Through novel reading, readers are not only entertained, but they also gain information that they may have not previously known. Moreover, it enables readers to construct their own imagination about how characters and places look like. In novels, numerous names which are unique and idiosyncratic, such as names of characters, places, and objects are often encountered. Names of this type are commonly labeled proper names.

Proper names usually begin with capital letters and convey information within [1]. Through these names, personal traits or physical appearance of characters in a novel can be represented. Besides, proper names can reveal particular characteristics of places and things. Thus, translating proper names is not an easy task for translators as they need to take the specific features of such linguistic units into consideration.

Translation of proper names has been main interest of numerous researches. Included in researches on how proper names are translated are researches conducted by Sabzalipour and Pishkar [2] and Shirinzadeh and Mahadi [3]. Research investigating equivalence in proper name translation was done by Suhardi, Widodo and Setiawan [4]. Another research conducted by Widiyantari, Atmaja, \& Saptaningsih [5] covers wider area of investigation: how proper names 
are translated and how it affects the translation quality. This research focuses on studying the translation of proper names in the novel The Slippery Slope from English into Indonesian concerning its form, meaning, and stylistic effect. The data of this research are proper names, identified not only as typical proper names, but also as unique proper names consisting of names which have alliteration and names denoting the full forms of an organization name in the novel.

\section{Literature Review}

\subsection{Proper Names}

Proper names are names of particular persons, places, organizations or things which usually begin with capital letters (Collins Dictionary) [6]. In line with this definition, Sinclair [1] asserts that proper nouns or names always start with a capital letter and refer to a person, place, or institution. From the previous statements, the main features of proper names are that they refer to people, places, and things and are initialized with capital letters.

Other than that, Matthews (1997, p. 300) defines proper name as "the name of a specific individual or of a set of individuals distinguished only by their having that name" (as cited in Fernandes, 2006, p. 45) [7]. Similar to Matthews, Nord [8] describes the definition of name as the word by which an individual referent is identified, whose main function is to identify, for instance, an individual person, animal, place, or thing. This means that proper names can portray the characteristics of an individual. In addition, Nord [8] affirms that proper names "are obviously not non-informative", which indicates that proper names convey information within the names. For example, Jakarta refers to a geographical name, in particular, the capital city of Indonesia.

Proper names in literature, tantamount to the ones in novel, have supplemental features. This is asserted in the following account, "With regard to literary characters, the names are primary name-formations in the sense that they are new coinages... The names of literary characters are surely not chance formation as the degree of motivation between the name and its referent is transparently stressed" (Bertills, 2003, p. 44) [9].

Some names do not suggest meaning. However, a lot of proper names also have certain reference indicating meaning. According to Gardiner [10], there are names that are absolutely arbitrary and names that contain meaning by the suggestions attached to the name. Proper names, hence, can be classified into two categories, namely pure and less pure names [10]. Pure names are arbitrary and denotative. On the contrary, less pure names indicate meaning and, thereof, are connotative. Further, connotations in the names of this type are viewed as what is asserted by Bertills [10], "Commonly, the connotations of semantically loaded names are still connected to the features of the names".

\subsection{Translation of Proper Names}

Translating proper names is a challenging task for translators. Hramova [11] states that translators must be "able to read the name as an intertextual fragment and analyze the associations - cultural, linguistic and literary - in order to see the system of that fragment and render it in the TL accordingly". Hence, a translator must be aware of the meaning suggested by a proper name in order to render it properly. 


\section{Methodology}

This research is a descriptive qualitative research aimed to study how proper names in the novel "The Slippery Slope" are translated from English into Indonesian concerning the form, meaning, and stylistic effect in the source language (SL) and target language (TL). The data of this study are proper names found in The Slippery Slope novel. The data were collected by means of content analysis and analyzed using Miles and Huberman's [12] interactive data analysis consisting of data reduction, data display and conclusion drawing. Firstly, the data were obtained by content analysis. This research selected only the proper names and discarded other irrelevant elements in the novel The Slippery Slope. Secondly, a total of 114 data were displayed by categorizing them into typical proper names and unique proper names. Moreover, each category is divided into the subcategory of personal names, animal, plant, inanimate objects, and geographical names. Next, the meaning, form, and stylistic effect of the data were analyzed. Lastly, the conclusion is drawn based on the result of the data analysis.

\section{Findings and Discussion}

This research classified the data into 2 categories, namely typical proper names and unique proper names and divided each category into personal names, animal, plant, inanimate objects, and geographical names. Personal names are names which belong to particular people. Names of inanimate objects consist of all non-living objects which do not contain geographical features, such as food, literary work, day, song, and language. Lastly, geograpical names are names containing geographical features.

\section{Typical Proper Names}

The label "typical proper names" are attached to proper names with lack of stylistic properties in contrast to the other category of proper names in this research. Within this category are proper names which only bear the relationship between names and referents, labeled as denotation (Bertills, 2003, p. 25) [9]. The example can be seen in Table 1.

Table 1. Example of typical proper name: Sunny.

\begin{tabular}{|l|l|}
\hline \multicolumn{1}{|c|}{ ST } & \multicolumn{1}{c|}{ TT } \\
\hline $\begin{array}{l}\text { Sunny was the youngest Baudelaire, still learning } \\
\text { to speak in a way that everyone could understand, } \\
\text { so she scarcely had words for how frightened she } \\
\text { was. }\end{array}$ & $\begin{array}{l}\text { Sunny adalah anak termuda Baudelaire, masih } \\
\text { belajar bicara dengan cara yang dapat } \\
\text { dimengerti setiap orang, jadi ia hampir tak punya } \\
\text { kata-kata untuk menjelaskan betapa takutnya ia } \\
\text { sekarang. (p. 6) }\end{array}$ \\
\hline
\end{tabular}

Sunny is the name of the youngest Baudelaire children. This typical proper name belongs to the subcategory of personal names. The proper name "Sunny" is translated as it is in Indonesian since the name is arbitrary and suggests no meaning. This indicates that the translator has rendered the proper name in the source text (ST) into the same form in the target text (TT), which is personal name. Hence, the proper name is lack of stylistic effect.

In addition to the subcategory of personal names, the data of typical proper names also contain names of inanimate objects. The example can be seen in Table 2 . 
Table 2. Example of typical proper name: False Spring Rolls.

\begin{tabular}{|l|l|}
\hline \multicolumn{1}{|c|}{ ST } & \multicolumn{1}{|c|}{ TT } \\
\hline $\begin{array}{l}\text { "The False Spring Rolls were quite tasty, and the } \\
\text { lox was delicious." (p. 157) }\end{array}$ & $\begin{array}{l}\text { "Lumpia Musim Semi Palsu cukup lezat dan } \\
\text { salmon asapnya enak." (p. 301) }\end{array}$ \\
\hline
\end{tabular}

The name simply refers to spring rolls that are fake. The ST word 'false' means fake and 'palsu' is its equivalent meaning in the TT. 'Spring roll' is a type of Asian snack consisting of rice paper filled with minced vegetables and usually meat, rolled into a cylinder and fried (Lexico) [13]. In Indonesia, a snack having similar meaning to spring roll is called 'lumpia'. According to Collins Dictionary [14] the word 'spring' refer to a season between winter and summer when plants start to grow again. The equivalent meaning of 'spring' in the TT is 'musim semi'. Thus, by translating False Spring Rolls into Lumpia Musim Semi Palsu in the TT, the translator has been successful in rendering the meaning of the proper name.

Another example of typical proper names which belongs to the category of geographical names can be seen in Table 3.

Table 3. Example of typical proper name: House of Freaks.

\begin{tabular}{|l|l|}
\hline \multicolumn{1}{|c|}{ ST } & \multicolumn{1}{|c|}{ TT } \\
\hline $\begin{array}{l}\text { The caravan had served as a home for several } \\
\text { performers at the carnival's House of Freaks } \\
\text { before they defected }- \text { a word which here means } \\
\text { "joined Count Olaf's band of revolting } \\
\text { comrades" (p. 7) }\end{array}$ & $\begin{array}{l}\text { Keberapa penampil di Rumah Orang-Orang } \\
\text { Aneh sebelum mereka menjadi rusak - kata yang } \\
\text { di benijarti "bergabung dengan kelompok } \\
\text { menjijkan Count Olaf". (p. 14) }\end{array}$ \\
\hline
\end{tabular}

This proper name refers the name of an attraction in a carnival. The word 'house' is often used to refer to a building based on what it has inside. It has an equivalent meaning in Indonesian that is "rumah". For example, in Indonesia, the word is often used such as in "rumah baca" which means a particular place for people to read books and "rumah cermin" which refers to a place having lots of mirrors enabling people to play with their reflections. Meanwhile, a 'freak' means a thing, person, animal, or event that is extremely unusual and unlike any other of its type. Thus, the translator translates the proper name "House of Freaks" into its equivalent meaning "Rumah Orang-Orang Aneh" which refers to the place occupied by freaky people.

The other category consists of names which are still connected to the features of the names. The example can be seen in Table 4.

Table 4. Example of typical proper name: Babylaire.

\begin{tabular}{|l|l|}
\hline \multicolumn{1}{|c|}{ ST } & \multicolumn{1}{|c|}{ TT } \\
\hline $\begin{array}{l}\text { "Where are you, Babylaire?" he asked, adding } \\
\text { an absurd nickname to his list of insults. "I've } \\
\text { thought of more tasks for you to perform." (p. }\end{array}$ & $\begin{array}{l}\text { nama panggilan aneh pada salah satu daftar } \\
\text { hinaannya. "Aku punya pekerjaan lain yang harus } \\
\text { 112) }\end{array}$ \\
\hline
\end{tabular}


The proper name "Babylaire" is mentioned by the evil villain in the novel, Count Olaf, when he is looking for the youngest child of the Baudelaire, Sunny. This nickname indicates the physical appearance of Sunny who is still a baby. This name, thus, indicates that proper name can represent an individual with their own characteristics distinguished by having that name.

In this case, the surname "Baudelaire" is turned into an insulting nickname "Babylaire". The proper name "Babylaire" has been cleverly translated into "Bayilaire" by the translator. In Indonesian, the word 'baby' has an equivalent word 'bayi' which means a very young child who is just recently born. The translator has successfully preserved the meaning of the proper name and translated an insult into an insult, hence preserving the form of the proper name.

\section{Unique Proper Names}

Unique proper names, the term used in this study, refer to proper names bearing sylistic effects in addition to the distinctive attributes making them proper names. One type of unique proper names covers those which can be abbreviated as V.F.D., spreading throughout the novel. The example can be seen in Table 5.

Table 5. Example of unique proper names: form-loaded proper names.

\begin{tabular}{|l|l|}
\hline \multicolumn{1}{|c|}{ ST } & \multicolumn{1}{|c|}{ TT } \\
\hline "And then there were the snow gnats," & \multicolumn{1}{|c|}{ "Kemudian ada serangga salju!", } \\
Violet said. "They behaved like \\
kiolent Frozen Dragonflies." (p. 43) & $\begin{array}{l}\text { seperti Pasukan Kertingekuan } \\
\text { Seram". (p. 85) }\end{array}$ \\
\hline
\end{tabular}

Similar to the previous examples, a preservation of the form of proper names in the translation of the name of the animal "Violent Frozen Dragonflies" also exists. It is translated as "Pasukan Kebekuan Seram". In this case, the Baudelaire siblings are figuring out the full form of a name of a secret organization abbreviated as "V.F.D.". This organization has standardized secret codes referred to that abbreviated form. The above example is one of the names denoting the secret organization which are consistently translated into "P.K.S." in the TT.

According to Cambridge Dictionary [15], 'dragonflies' are long, thin insects which have two pairs of transparent wings. The head noun is translated into the word 'pasukan' in the TT, which means 'a group of people or things classed together', in order to maintain the translation of the abbreviated form of the name which starts with letter ' $p$ ', although they are not equivalent in meaning. Meanwhile, the adjective 'frozen' which means 'turns into ice' is translated as a noun in Indonesian as 'kebekuan' in order to preserve the second initial of the abbreviated form. Furthermore, the adjective 'violent' is translated also as an adjective into 'seram'. The word 'violent' is used to describe a hurtful situation in which people are attacked or killed [16]. It is associated as a horrible situation. Therefore, translating the ST word 'violent' into the TT word 'seram' is considered as an appropriate decision. Thus, the translator has been successful in preserving the abbreviated form of the name of organization and maintaining the stylistic effect.

A different category of unique names covers proper names featured with alliteration (sound repetition), as exemplified by the following example in Table 6. 
Table 6. Example of the translation of form-loaded proper names (alliteration).

\begin{tabular}{|l|l|}
\hline \multicolumn{1}{|c|}{ ST } & \multicolumn{1}{c|}{ TT } \\
\hline $\begin{array}{l}\text { The caravan's journey grew rougher and } \\
\text { rougher, and with each jolt, the }\end{array}$ & $\begin{array}{l}\text { Jalan yang dilalui caravan semakin tidak } \\
\text { rata. Dan dengan setiap guncangan, } \\
\text { Baudelaires felt a bit seasick, as if they } \\
\text { anak-anak Baudelaire merasa sedikit } \\
\text { were back on Lake Lachrymose, } \\
\text { mabuk laut, seakan mereka kembali ke } \\
\text { crossing its stormy waters to try and } \\
\text { rescue one of their many unfortunate } \\
\text { guardians. (p. 9) }\end{array}$ \\
$\begin{array}{l}\text { yang penuh badai untuk mencoba } \\
\text { menyelamatkan salah satu wali mereka } \\
\text { yang bernasib malang. (p. 19) }\end{array}$ \\
\hline
\end{tabular}

The ST word 'lachrymose' means sorrowful. It is translated into its equivalent meaning in the TT, ' $d u k a$ '. The name of the lake indicates that it has given a horrible experience for the characters in the novel, the orphaned Baudelaire siblings. This name is an alliteration and is also translated into alliteration with equivalent meaning in Indonesian. This indicates that the translator of the novel the translator preserves not only the meaning but also the form of the name.

The findings of this research reveal that the translator renders the proper names which belong to the category of typical proper names by translating them into the TT as they are (for the personal names) or translating them into their equivalent meanings in the target language. The proper names which belong to the category of unique proper names consist of names which have alliteration and form-loaded names, in this case, the names which are consistently translated into the same initialism as thereof in the ST. The unique proper names were rendered properly, considering the meaning suggests by each name, the form of the names and the stylistic effect created by the names.

Translating proper names is not an easy task. Ibraheem [17] pointed out that how proper names in translation are treated is not a trivial issue but it has rather the same degree of complexity as other expressions which require a delicate decision -making process of careful consideration to pragmatic function and the semantic one in the given context knowing that translation is more than linguistic exercise but rather an act of communication involving transaction of information from the author of the original text to the target reader.

Translating proper names is also not easy in the way that many factors have to be put into consideration. As the novel is a type of literary text, which emphasizes not only content, effect embedded in it is one of the factors to be made consideration. Emphasized by Vermes [18], "the type and function of a text is an important factor in making decisions about the rendering of proper names". A considerable number of proper names in the investigated novel are translated by preserving the effects they carry. This goes in line with a case put forward by Vermes in which "Winnie the Pooh" is translated into "Micimakko", a name which "evokes the image of funny and loveable teddy bear".

In addition, although Zarei [19] claimed that achieving absolute equivalence in the translation of proper names because of the specific aspects in the languages, what the translators do in this process is attempting to retain authentic effect achieved by the names and to improve transliteration accuracy. Names are preserved in terms of the way they sound and translated by making use of different translation strategies to find appropriate ways to render proper nouns. 


\section{Conclusion}

The proper names which belong to the category of typical proper names are translated into the target language as they are due to the arbitrariness of the names, or translated into their equivalent meaning in the TL. On the contrary, the proper names which belong to the category of unique proper names are rendered from the SL into the TL in a proper way, considering the meaning, form, and stylistic effect. Thus, in translating proper names, a translator is also expected to preserve the form and stylistic effect of the names, in addition to the meaning conveyed by the proper names.

\section{References}

[1] Sinclair J. Collins cobuild - english grammar digital edition. London: William Colins Sons \& Co Ltd.

[2] Sabzalipour M, Pishkar K. Translation of proper nouns in children's literature. J Apl Ling Lang Res. 2015; 2(6):73-79.

[3] Shirinzadeh SA, Mahadi TS. Translating proper nouns: a case study on english translation of hafez's lyrics. Eng Lang Teach. 2014; 7(7):8-16.

[4] Suhardi, Widodo P, Setiawan T. Equivalence of proper names in foreign languages in the Indonesian language. Int J Ling Lit Teach. 2019; 18:1-16.

[5] Widiyantari Y, Atmaja AK, Saptaningsih N. Proper names in sherlock holmes' novel the sign of four into its Indonesian translation. Eng Lang Lit Int Con. 2017; 1:394-397.

[6] 'Proper noun', Collins Dictionary, Available: https://www.collinsdictionary.com/dictionary/english/proper-noun.

[7] Fernandes L. Translation of names in children's fantasy literature: bringing the young reader into play. New Voices in Translation Studies. 2006; 2:44-57.

[8] Nord C. Proper names in translation for children: alice in wonderland as a case in point. Meta. 2003; 48(1-2): $182-196$.

[9] Bertills Y. Beyond identification. Proper names in children's literature. Finland: Åbo Akademi University Press; 2003.

[10] Gardiner A. The Theory of Proper Names: A Controversial Essay. Second edition. London: Geoffrey Cumberlege, Oxford University Press.

[11] Hramova T. 'Poetry in the raw': Defining and translating proper names in literature. Procedia - Social and Behavioral Sciences. 2016; 231:159 - 164.

[12] Miles, Huberman AM. Qualitative data analysis: an expanded sourcebooks, 2nd ed. London: SAGE Publication; 1994.

[13] 'Spring roll', Lexico, Available: https://www.lexico.com/definition/spring_roll.

[14] 'Spring', Collins Dictionary, Available: https://www.collinsdictionary.com/dictionary/english/spring

[15] 'Dragonfly', Cambridge Dictionary, Available: https://dictionary.cambridge.org/dictionary/english/dragonfly.

[16] 'Violent', Cambridge Dictionary, Available: https://dictionary.cambridge.org/dictionary/english/violent

[17] Ibraheem AK. Proper names: translating reference and application. J Col Basic Edu. 2016; 21(92):112.

[18] Vermes AP. Proper names in translation: a relevance-theoretic analysis. 2001.

[19] Zarei R, Norouzi S. Proper nouns in translation: should they be translated? Intel J Appl Ling \& Eng Lit. 2014; 3(6):152-161. 